\title{
Environmental impacts and the possibility for sustainable development of human excreta
}

\author{
A. Zseni \& J. Nagy \\ Széchenyi István University, Hungary
}

\begin{abstract}
The aim of our study is to explore and compare the environmental impacts and the sustainability of two different human excreta collection and treatment methods. We systematized and compared the environmental impacts of flush toilet based water infrastructure and composting of human excreta. Among the factors examined the energy demand of wastewater treatment, the nitrogen and phosphorus loading caused by purified sewage emission, the loss of nutrients of human excreta, the quantity of fertilizer used for increase soil productivity are highlighted and presented by Hungarian data. According to our approximate calculations, the excreta which are produced by humans in Hungary contain about 35-70 thousand tons of nitrogen, 4-13 thousand tons of phosphorus, 6-16 thousand tons of potassium annually. In spite of this human excreta are considered as waste which must be clear away as fast as possible by water. Meanwhile increasing amount of chemical fertilizers are used - but soil nutrient supply based on chemical fertilization cannot be sustainable in the long term. The solution would be the utilization of composted excreta in the agriculture.
\end{abstract}

Keywords: flush toilet, wastewater treatment, human excreta, composting of human excreta, environmental effects.

\section{Introduction}

The wide-spread use of flush toilets changed people's attitude to their excreta especially in the developed world. Human excreta became waste which must be cleared away as fast as possible by water. The overall environmental effects caused by a flush toilet based water infrastructure can be classified into several wellknown sets of problems: e.g. non-sustainable use and waste of natural resources, energy demand, inorganic $\mathrm{N}$ and $\mathrm{P}$ pollution of surface and underground water, GHG emissions. However, the greatest environmental harm of a flush toilet based 
infrastructure is the withdrawal of the very valuable organic matter and nutrient content of human excreta from the cycle of the biosphere. Human excreta - as biomass - are essential components of material and energy flow of ecosystem. It may cause a lot of long-term environmental problems and upset the natural circulation of carbon, nitrogen, phosphorous and water, if excreta are taken out of the natural cycles or transported to an inappropriate environmental medium in an inappropriate chemical form. We have gotten into a vicious circle discharging human excreta to freshwater: wastewater treatment converts human excreta to water pollutants, while we replace missing nutrients to soils artificially, which leads to the exploitation of soils in the long run.

Utilization of human excreta for agricultural purposes has been known for thousands of years, but it was not widespread everywhere and at all times. There are several techniques used: urine manure, pelleting of faeces, composting of excreta with plant biomass etc. Composting of excreta has a lot of positive environmental effects as it allows humus forming from the organic matter content of excreta. However, especially in the developed world, composting of human excreta is not self-evident for people - primarily because of cultural and psychological reasons.

\section{Environmental effects: the flush toilet versus composting of human excreta}

Joseph Bramah registered the invention of flush toilet tank in 1788. Initially, the flush toilets served only the comfort of rich peoples and were not connected to the greywater sewage systems. Later, as a result of industrialization, connection of flush toilets to the drinking water and sewer system became widespread because of comfort and hygiene needs of the increased number of inhabitant of cities. After collection, sewage water was usually emitted to surface water. The negative effects of unclean sewage on surface water and on human health focused attention to water. However, it was not considered how to avoid entering of human excreta the water cycle. More and more advanced wastewater treatment technologies have been built and applied. The faecal nitrogen and phosphorus content are broken down and converted to nitrate and inorganic phosphate. These cause the eutrophication of water, so wastewater treatment has to become more and more effective to avoid pollution of water. Instead, inorganic $\mathrm{N}$ and $\mathrm{P}$ accumulate in the sludge and a small part gets into the atmosphere (in the form of $\mathrm{N}_{2}$ ).

Composting of human excreta offers appropriate and suitable technology to take back our excreta into the natural cycles and the well-known environmental problems caused by flush toilet based infrastructure can be reduced or even eliminated (Pereira-Neto et al. [1], Drangert [2, 3], Schönning and Stenström [4], Bracken et al. [5], Wichuk and McCartney [6], Niwagaba [7], Cameron et al. [8], Polprasert [9], Országh [10]). As treatment of greywater needs more simple techniques than treatment of sewage containing blackwater, wastewater treatment techniques can be modified. More simple wastewater technologies cause significant energy saving and thereby the use of energy resource and $\mathrm{CO}_{2}$ emission 
decrease as well. Composting and utilization of excreta in agriculture may reduce the amount of fertilizers used, which may result in decrease of mineral and energy demand, and therefore decrease of $\mathrm{CO}_{2}$ emission. If the nutrient content of excreta returned to the natural biological cycles, we would be able to take steps to achieve sustainable food production.

In Table 1 the most significant environmental impacts of flush toilet based water infrastructure are summarised and compared to composting of human excreta, based our earlier works (Zseni [11-13], Zseni and Nagy [14]).

Table 1: Environmental effects of flush toilet and composting of human excreta.

\begin{tabular}{|c|c|}
\hline $\begin{array}{c}\text { Environmental effects caused by } \\
\text { flush toilet }\end{array}$ & $\begin{array}{c}\text { Environmental effects caused by } \\
\text { composting of human excreta }\end{array}$ \\
\hline Changes in natural water cycle. & It does not intervene in the natural water \\
cycle.
\end{tabular}


Table 1: Continued.

\begin{tabular}{|c|c|}
\hline $\begin{array}{c}\text { Environmental effects caused by } \\
\text { flush toilet }\end{array}$ & $\begin{array}{l}\text { Environmental effects caused by } \\
\text { composting of human excreta }\end{array}$ \\
\hline $\begin{array}{l}\text { We need to use artificial fertilizer to } \\
\text { enhance soil productivity and this } \\
\text { generates negative impacts on the } \\
\text { environment and demands energy and } \\
\text { mineral resources. }\end{array}$ & $\begin{array}{l}\text { Use of fertilizer and slurry decreases } \\
\text { significantly, so their unfavourable } \\
\text { environmental effects and use of energy } \\
\text { and mineral resources also decrease. }\end{array}$ \\
\hline $\begin{array}{l}\text { Fertilization causes more rapid } \\
\text { decomposition of soil humus content, } \\
\text { which worsens structure, water } \\
\text { management property, chelating, } \\
\text { adsorption and puffer capacity of } \\
\text { soils, too. }\end{array}$ & $\begin{array}{l}\text { Exploitation of soils and soil erosion } \\
\text { decrease. }\end{array}$ \\
\hline Food production is not sustainable. & $\begin{array}{l}\text { Food production becomes more } \\
\text { sustainable. }\end{array}$ \\
\hline $\begin{array}{l}\text { Wastewater treatment is not able to } \\
\text { remove drug residues and hormones } \\
\text { from water. }\end{array}$ & $\begin{array}{c}\text { Drug residues and hormones are } \\
\text { degraded by composting of human } \\
\text { excreta. }\end{array}$ \\
\hline $\begin{array}{c}\text { Heavy metals may be accumulated in } \\
\text { wastewater sludge because of common } \\
\text { treatment of industrial and household } \\
\text { wastewater. }\end{array}$ & $\begin{array}{c}\text { Human excreta has very low heavy metal } \\
\text { concentration and heavy metal is } \\
\text { originated from the food (harvested } \\
\text { crop). }\end{array}$ \\
\hline $\begin{array}{l}\text { Utilization of human excreta without } \\
\text { prior treatment in agriculture (like non- } \\
\text { composted manure and slurry, and } \\
\text { sucked liquid municipal waste): the } \\
\text { bacterial and helminthic eggs content of } \\
\text { these are very high. }\end{array}$ & $\begin{array}{l}\text { The faecal bacteria content of properly } \\
\text { composted human excreta is } \\
\text { insignificant, even the helminthic eggs } \\
\text { are destroyed during the long period of } \\
\text { composting. }\end{array}$ \\
\hline
\end{tabular}

\section{Environmental impacts of flush toilet based infrastructure: example of Hungary}

In this section the environmental effects caused by flush toilet based water infrastructure are presented through the example of Hungary, based on statistical data. Environmental impacts are grouped to (i) demand of natural resources, (ii) pollution by domestic sewage, (iii) non-sustainable use of human excreta.

\subsection{Demand of natural resources}

\subsubsection{Water demand}

Using of flush toilet has changed our water consumption habits and increased the water consumption of households. Nowadays thanks to the spread of water-saving 
approaches and techniques we use less water for flushing the toilet, but flushing still adds up to $15-20 \%$ of household water consumption. People in Hungary connected to sewer system use drinking water for flushing the toilet.

In Hungary, the public water production was $581,121,000 \mathrm{~m}^{3}$ in 2014 , of which water consumption of households was $326,122,000 \mathrm{~m}^{3}$ (HCSO [15]). It means $33.02 \mathrm{~m}$ /person/year, approximately $90.5 \mathrm{l} /$ day/person. (Number of inhabitants in Hungary is 9,823,000 (01.01.2016) (HCSO [15]).) 94.7\% of households and all the 3154 settlements are connected to drinking water pipes system. In Hungary, $94 \%$ of drinking water is originated from underground water.

$500,882,000 \mathrm{~m}^{3}$ of sewage water is collected in public sewage network (encompasses households and other municipal consumers) in 2014, of which $481,057,000 \mathrm{~m}^{3}$ of sewage water was transported to wastewater treatment plants (2014) (HCSO [15]). 2,746,000 $\mathrm{m}^{3}$ of sewage water was collected and transported not by public sewage network to wastewater treatment plants. $77 \%$ of households are connected to sewer system and 1900 settlement $(60.2 \%)$ are supplied with sewer system (2014) (HCSO [15]). There is no official statistical data about the sewage water transported from households, but we can assume at least $250,000,000 \mathrm{~m}^{3}$ of sewage water ( $77 \%$ of total water consumption of household) which originates from households connected to sewer system.

Most of the wastewater treatment plants emit their treated water to surface water bodies. It means that most people in Hungary use underground water for the purpose of flushing the toilet, but water from the toilet is emitted to surface water.

\subsubsection{Energy demand}

Collection and treatment of sewage water is energy-consuming process. The average energy consumption of wastewater treatment plants is about $20 \%$ of the total municipal electricity consumption, if we do not take into consideration the wastewater treatment plant's own electricity production (Christ and Mistsdoerffer [16]). In Table 2 the energy consumption (median of the measured data) of wastewater treatment plants (wwt plans) sorted according to their capacity (population equivalent, PE) are summarized, based on Hungarian examinations. Our investigations in different Hungarian wastewater treatment plants are included, too.

Operation of sewage drainage systems needs energy, too, and its energy demand is not negligible. In the case of two small wastewater treatment plants we present also data of energy demand of sewage collection. For example, the energy demand of sewage collection in the wastewater treatment agglomeration of Tét is $24 \mathrm{kWh} / \mathrm{PE} /$ year, while in the case of Jánossomorja it is $32.4 \mathrm{kWh} / \mathrm{PE} /$ year.

Wastewater treatment plants are able to produce part of their energy demand by treatment of sludge (biogas production by sludge digestion). For example, the Budapest Central Wastewater Treatment Plan has a total energy demand of $90,000 \mathrm{kWh} /$ day, and it can produce $60,000 \mathrm{kWh} /$ day energy with the help of biogas originated from sludge digestion. The biogas burning covers half of the energy demand of the wastewater treatment plant of Györ. Nevertheless, biogas burning causes $\mathrm{CO}_{2}$ emission (see chapter 3.2.2) and wastes the valuable organic 
matter and nutrient content of excreta. The price of electricity generated by sludge treatment varies widely and sometimes it is not competitive (Domokos [17]).

Table 2: Energy consumption of wastewater treatment plans.

\begin{tabular}{|l|c|l|l|c|}
\hline $\begin{array}{c}\text { Investigated wwt plans in Hungary, } \\
\text { based on Domokos [17] }\end{array}$ & \multicolumn{3}{|c|}{ Selected wwt plans in Hungary } \\
\hline $\begin{array}{c}\text { Capacity } \\
\text { (PE) }\end{array}$ & $\begin{array}{c}\text { Energy } \\
\text { consumption } \\
\text { (kWh/PE/year) }\end{array}$ & WWT plan & $\begin{array}{c}\text { Capacity } \\
\text { (PE) }\end{array}$ & $\begin{array}{c}\text { Energy } \\
\text { consumption } \\
\text { (kWh/PE/year) }\end{array}$ \\
\hline over 15000 & 26.3 & Budapest, CWTP & 1260000 & 26 \\
\hline $2500-15000$ & 37.8 & Györ & 175000 & 25 \\
\hline $300-2500$ & 61.9 & Tét & 7000 & 55 \\
\hline $0-300$ & 108.4 & Jánossomorja & 6800 & 21.4 \\
\hline & & Tiszaalpár & 5500 & 44.8 \\
\hline
\end{tabular}

\subsection{Pollution load of domestic sewage}

\subsubsection{Water pollution by domestic sewage}

Distribution of pollution load of urban wastewater shows that $99 \%$ of bacteria originates from faeces; $11 \%$ of $\mathrm{N}$-content originates from faeces, $87 \%$ from urine and $2 \%$ from greywater (GW); $40 \%$ of P-content originates from faeces, $50 \%$ from urine, $10 \%$ from $\mathrm{GW} ; 47 \%$ of organic matter content originates from faeces, $12 \%$ from urine, $41 \%$ from GW (Toilettes du Monde [18]). So $99 \%$ of bacteria, $98 \%$ of $\mathrm{N}$-content, $90 \%$ of $\mathrm{P}$-content and the total amount of drug residues and hormones are in the human excreta, which amounts to less than $2 \%$ of the total wastewater volume. The use of flush toilets produces blackwater. As in Hungary blackwater and greywater are together both in the sewage systems and in wastewater treatment plants, the total amount of wastewater needs being treated by well-known treatment technologies.

In Hungary, $4.4 \mathrm{~kg} /$ person $\mathrm{N}$ and $1 \mathrm{~kg} /$ person $\mathrm{P}$ estimated data are used for calculation of the annually emission of the population connected to wastewater treatment plants (HCSO [19]). According to this, 44 thousand tons of $\mathrm{N}$ and 10 thousand tons of $\mathrm{P}$ is removed from households by sewage system, which data included the $\mathrm{N}$ and $\mathrm{P}$ in greywater also. As $98 \%$ of $\mathrm{N}$ and $90 \%$ of $\mathrm{P}$ originate from blackwater (see above), an estimated 44 thousand tons of $\mathrm{N}$ and 9 thousand tons of $\mathrm{P}$ in the sewage originate from human excreta annually in Hungary. (These data meet our calculated data according to which 35-70 thousand tons of $\mathrm{N}$ and 4-13 thousand tons of $\mathrm{P}$ are in the excreta of 10 million people (see section 4.1).)

The estimated emission of Hungarian households after wastewater treatment is an average $1.5 \mathrm{~kg} /$ person $\mathrm{N}$ and $0.35 \mathrm{~kg} /$ person $\mathrm{P}$ (emission differs by region, due to different effectiveness of wastewater treatment in the different regions) (HCSO [19]). According to this, emission of 15 thousand tons of $\mathrm{N}$ and 3.5 thousand tons of $\mathrm{P}$ to freshwater are assumed annually in Hungary. So about $1 / 3$ of $\mathrm{N}$ and $\mathrm{P}$ 
entering wastewater treatment plants get to freshwater after treatment (in the form of inorganic nitrate and phosphate). The remaining $2 / 3$ of $\mathrm{N}$ and $\mathrm{P}$ are in the sludge and part of $\mathrm{N}$ gets to the atmosphere (because of denitriphication in the anoxic tank of the activated sewage sludge treatment). Depending on the utilization of sludge (burning, digestion, composting etc.) part of $\mathrm{N}$ and $\mathrm{P}$ gets to soil (and might get to underground water bodies).

\subsubsection{GHG emission of domestic sewage}

During wastewater treatment the organic compounds of human excreta are broken down and converted into inorganic ions and compounds, including $\mathrm{CO}_{2}$. It is not sufficiently studied yet, how much $\mathrm{CO}_{2}$ is produced during biological treatment. As it depends on the oxidation rate of organic carbon compounds, which hinges on the circumstances and effectiveness of treatment, we are not able to give accurate and universally valid data.

Treatment methods of primary and excess sludge produced in wastewater treatment plants (sludge thickening, heating, pasteurization, digestion, dewatering etc.) depend on the final consumption of sludge. During these treatments the organic content of sludge (and after all the organic matter content of human excreta) is converted into inorganic ions and/or greenhouse gases.

In 2013, the total pollution load of all Hungarian municipal wastewater treatment plants was $8,750,148$ population equivalent $(\mathrm{PE})$ and the dry matter mass of sewage sludge was 179,378 tons (Stratégia 2014 Konzorcium [20]). $37.8 \%$ of sludge was used in agriculture, $45.7 \%$ of sludge was used for recultivation, $5.6 \%$ was used for power generation, $8.9 \%$ was used for other purposes and 2.0\% was dumped (Stratégia 2014 Konzorcium [20]). The average specific value of dry matter content of sewage sludge is $20.5 \mathrm{~kg} / \mathrm{PE}$ annually. Because of future developments 12.2 million PE and 250 thousand tons of dry matter sewage sludge are expected by 2027.

Digestion of sludge produces biogas which can cover part of the energy consumption of the plant. However, burning of biogas causes $\mathrm{CO}_{2}$ emission. If the total amount of sludge is treated by digestion and the produced biogas is burned, then we can assume that practically all the carbon content of organic compounds (so the total carbon content of human excreta as well) is converted to $\mathrm{CO}_{2}$ during wastewater and sludge treatment. Furthermore, operation of sewage drainage systems and wastewater treatment plants needs energy which - depending on the energy sources - also contributes to $\mathrm{CO}_{2}$ emission.

\subsection{Non-sustainable use of human excreta}

Once human excreta is removed by water from households, we are not able to regain its original organic material compounds. Flowing through the sewage pipes human excreta begin to degrade. Urease enzymes hydrolyse the urea content of urine and this reaction generates ammonium ion (and $\mathrm{CO}_{2}$ ). During wastewater treatment the ammonium is oxidized to nitrate and the organic phosphorus compounds of human excreta are converted into inorganic phosphates. So we can say that the valuable organic $\mathrm{N}$ and $\mathrm{P}$ compounds of human excreta are converted into water pollutants by wastewater treatment. However, the greatest 
environmental harm is not the water load, but withdrawal of the very valuable organic matter content of human excreta from the natural cycle of biosphere.

\section{Human excreta as a possibility for sustainable development}

\subsection{Nutrient content of human excreta}

Amount, appearance, physical and chemical features of human excreta (faeces + urine) heavily depend on human health, the quality and quantity of food and fluid consumed, the sweat, even climate. Faeces encompass water, indigestible materials passing through the intestinal track (e.g. fibres), gland secretion (e.g. gall), as well as pathogenic viruses, bacteria, helminth eggs. Urine mostly contains water and also plant nutrients in water-soluble form.

To know, how much valuable material is lost when we regard human excreta as waste, we have to calculate its nutrient content. There are several data concerning with quantity and composition of excreta, but there are no specific Hungarian measurements. Therefore, we reviewed the data in literature and used them to our calculations.

Tanguay [21] calculates $150-300 \mathrm{~g} /$ person/day faeces (dry matter content: 40 $81 \mathrm{~g} /$ person/day). In developed countries the volume of faeces is $80-140$ $\mathrm{g} /$ person/day (Niwagaba [7]). In developing countries where food encompasses more fibre but fewer meal the amount of faeces is about $350 \mathrm{~g} /$ person/day in rural areas and $250 \mathrm{~g} /$ person/day in urban areas (Feachem et al. [22]). $315 \mathrm{~g} /$ person/day faeces were measured in China (Gao et al. [23]), $520 \mathrm{~g} / \mathrm{person} /$ day in Kenya (Pieper [24]), 120-400 g/person/day in Thailand (Schouw et al. [25]). Tanguay [21] presented two extremes depending on meal habits: there are 5-7\% nitrogen $(\mathrm{N}), 3-5.4 \%$ phosphorus $\left(\mathrm{P}_{2} \mathrm{O}_{5}\right), 1-2.5 \%$ potassium $\left(\mathrm{K}_{2} \mathrm{O}\right), 40-55 \%$ coal $(\mathrm{C}), 4$ $5 \%$ calcium $(\mathrm{Ca})$ in the dry material of faeces. Jönsson et al. [26] had processed several literature data and recommended $1.5 \mathrm{~g} /$ person/day $\mathrm{N}, 0.5 \mathrm{~g} /$ person/day $\mathrm{P}$, $0.9 \mathrm{~g} /$ person/day $\mathrm{K}$ content of faeces in the case of Swedish people. Vinnerås et al. [27] measured average value of $72 \mathrm{~kg} /$ person/year faeces, in which 10 $12.6 \mathrm{~kg} /$ person/year dry matter content, 630-710 g/person/year N-content, 126 $250 \mathrm{~g} /$ person/year P-content, 280-540 g/person/year K-content were measured.

The amount of urine is about $1-1.3 \mathrm{l} / \mathrm{person} /$ day, whose moisture content is $93-$ $96 \%$, dry matter content is 50-70 g/person/day (Tanguay [21], Feachem et al. [22]). Other literature data on the amount of urine present $1500 \mathrm{~g} / \mathrm{person} /$ day (Vinnerås et al. [27]), 610-1090 g/person/day in Switzerland (Jönsson et al. [28], 600-1200 g/person/day in Thailand (Schouw et al. [25]). There are 15-19\% nitrogen $(\mathrm{N}), 2.5-5 \%$ phosphorous $\left(\mathrm{P}_{2} \mathrm{O}_{5}\right), 3.0-4.5 \%$ potassium $\left(\mathrm{K}_{2} \mathrm{O}\right), 11-17 \%$ coal $(\mathrm{C}), 4.5-6 \%$ calcium $(\mathrm{Ca})$ in the dry matter content of urine, depending on meal habits (Tanguay [21]). According to Swedish data, the urine contains 3700 $3830 \mathrm{~g} /$ person/year N, 250-340 g/person/year P, 820-1190 g/person/year K (Vinnerås et al. [27]). Jönsson et al. [26] had processed several literature data and recommended $11 \mathrm{~g} /$ person/day N, $0.9 \mathrm{~g} /$ person/day $\mathrm{P}, 2.4 \mathrm{~g} /$ person/day $\mathrm{K}$ in the urine of Swedish people. 
In Thailand 7.6-7.9 g/person/day $\mathrm{N}, \quad 1.6-1.7$ g/person/day $\mathrm{P}, \quad 1.8$ $2.7 \mathrm{~g} /$ person/day K were measured in the excreta (faeces + urine) (Schouw et al. [25]).

For the comparability of the above presented data we calculated and converted them into the unit of $\mathrm{kg} /$ person/year, for elemental nitrogen $(\mathrm{N})$, phosphorous $(\mathrm{P})$ and potassium $(\mathrm{K})$. In Table 3 our calculations are summarised.

Table 3: Average nutrient content of excreta (faeces + urine).

\begin{tabular}{|l|c|c|c|c|}
\hline $\begin{array}{l}\text { In faeces } \\
\text { and urine } \\
\text { together }\end{array}$ & $\begin{array}{c}\text { Our calculation } \\
\text { based on Tanguay } \\
\text { [21] } \\
\text { (kg/person/year) }\end{array}$ & $\begin{array}{c}\text { Based on Jönsson } \\
\text { et al. [26] } \\
\text { (Sweden) } \\
\text { (kg/person/year) }\end{array}$ & $\begin{array}{c}\text { Based on } \\
\text { Vinnerås } \text { et al. } \\
\text { [27] } \\
\text { (Sweden) } \\
\text { (kg/person/year) }\end{array}$ & $\begin{array}{c}\text { Based on Schouw } \\
\text { et al. } \text { [25] } \\
\text { (Thailand) } \\
\text { (kg/person/year) }\end{array}$ \\
\hline $\mathrm{N}$ & $3.5-6.9$ & 4.57 & $4.3-4.5$ & $2.8-2.9$ \\
\hline $\mathrm{P}$ & $0.4-1.26$ & 0.51 & $0.38-0.59$ & $0.58-0.62$ \\
\hline $\mathrm{K}$ & $0.57-1.56$ & 1.21 & $1.1-1.7$ & $0.66-0.99$ \\
\hline
\end{tabular}

The Swedish data may be used for representing the developed world, while data from Thailand may be used for representing the developing countries. The extremes of Tanguay [21] express better the high variety of eating habits around the world.

As there is no measured and published Hungarian data for the exact nutrient content of the excreta of Hungarian people, we used our calculated data based on Tanguay [21]. According to our conviction the extremes express better the various eating habits of people. The maximum value is characteristic for a meat eater who eats a lot, while the minimum value indicates the nutrient content of excreta of a small eater and vegetarian people.

Population of Hungary is almost 10 million. It means, that the excreta of Hungarian people contains about 35-70 thousand tons of nitrogen $(\mathrm{N}), 4-13$ thousand tons of phosphorous (P) and 6-16 thousand tons of potassium (K) in a year. In order to compare these amounts, we present the nutrient loss due to soil erosion and the quantity of fertilizer used for increasing soil productivity.

\subsection{Nutrient loss due to soil erosion in Hungary}

Soil loss in Hungary caused by soil erosion is about $80-110$ million $\mathrm{m}^{3}$ soil annually, which means 1.5 million tonnes of organic matter, 0.2 million tons of $\mathrm{N}$, 0.1 million tons of $\mathrm{P}_{2} \mathrm{O}_{5}$ and 0.22 million tons of $\mathrm{K}_{2} \mathrm{O}$ loss per year (Várallyai et al. [29]). This is 200 thousand tons of $\mathrm{N}, 44$ thousand tons of $\mathrm{P}$ and 183 thousand tons of K loss annually.

According to our calculation, N-content of excreta of Hungarian people covers $17-35 \%$, P-content covers $9-30 \%$ and K-content covers 3-9\% of these amounts. If we take into consideration that excreta are composted with plant biomass (this is the best way of composting of excreta), these proportions may be even higher as nutrients of plant biomass would increase the nutrient content of the composted human excreta. 


\subsection{Fertilizers used in Hungary}

The active ingredient content of fertilizers used in Hungary is 310 thousand tons of $\mathrm{N}, 58$ thousand tons of $\mathrm{P}$ and 72.5 thousand tons of K (HCSO [19]). Nutrient content of excreta of Hungarian people could cover 7-22 percent of these. If excreta are composted with plant biomass, this value may be higher. Keep in mind that about $2 / 3$ of the artificial fertilizers is not utilized by plants (but causes surface and underground water loading), while the utilization rate is higher in the case of manuring with composted excreta.

Nitrogen and phosphorous balances of soils in Hungary are much less favourable compared to the rest of the EU member states, and both nitrogen and phosphorus balances were the lowest in Hungary in 2008 (N: -18 kg/hectare of agricultural area, P: $-15 \mathrm{~kg} /$ hectare of agricultural area) (HCSO [30]). As phosphorus is less mobile than nitrogen, the surplus $\mathrm{P}$ remaining in the soil accumulates year by year, and increases the dissolved and total phosphorus content of the soil. Nevertheless, the phosphorus balance of soils was negative in all years between 2000 and 2013 in Hungary, which may threaten already the sustainability of production (HCSO [30]).

\section{Conclusion}

The operation and maintenance of a flush toilet based water infrastructure have a high environmental price. During wastewater treatment the valuable organic components of human excreta are transformed into water loading inorganic $\mathrm{N}$ and $\mathrm{P}$ compounds. The improvement of end of pipe - wastewater treatment technologies is believed for perfect solution of the problems. However, this load is not the most harmful environmental effect of a flush toilet. The greatest environmental harm of a flush toilet is the withdrawal of the very valuable organic matter and nutrient content of human excreta from the natural cycle of biosphere. Nevertheless, human excreta is also part of the biosphere, and its leading back into natural cycles is the essential basis of future food production.

Because of freshwater pollution, the decreasing amount of good quality water resources and the effects of global warming we need to shift and use such methods which reduce water consumption and prevent water pollution. Moreover, regarding the annually loss of soil mass and soil fertility on the Earth, and the cost, material and energy demand of fertilizer production and utilization, we need more widespread agricultural utilization of human excreta in any case in the future.

\section{References}

[1] Pereira-Neto, J.T., Stentiford, E.I. \& Mara, D.D., Slow cost controlled composting of refuse and sewage sludge. Water Science and Technology, 19, pp. 839-845, 1987.

[2] Drangert, J.O., Fighting the urine blindness to provide more sanitation options, Water SA, 24(2), pp. 157-168, 1998. 
[3] Drangert, J.O., Urine blindness and the use of nutrients from human excreta in urban agriculture. GeoJournal, 45(3), pp. 201-208, 1998.

[4] Schönning, C. \& Stenström, T.A., Guidelines for the Safe Use of Urine and Faeces in Ecological Sanitation. Report 2004-1. Ecosanres, SEI: Sweden, pp. 22-23, 2004.

[5] Bracken, P., Wachtler, A., Panesar, A.R. \& Lange, J., The road not taken: how traditional excreta and greywater management may point the way to a sustainable future. Water Science \& Technology: Water Supply, 7(1), pp. 219-227, 2007.

[6] Wichuk, K.M. \& McCartney, D., A review of the effectiveness of current time-temperature regulations on pathogen inactivation during composting. Journal of Environmental Engineering Science, 6, pp. 573-586, 2007.

[7] Niwagaba, C.B., Treatment Technologies for Human Faeces and Urine, Doctoral Thesis. Swedish University of Agricultural Sciences: Uppsala, pp. 1-89, 2009.

[8] Cameron, D., Osborne, C., Horton, P. \& Sinclair, M., A sustainable model for intensive agriculture. Grantham Centre briefing note, Grantham Centre for Sustainable Futures \& The University of Sheffield: Sheffield, pp. 2-3, 2015.

[9] Polprasert, C., Organic Waste Recycling: Technology and Management. IWA Publishing: London, pp. 88-139, 2016.

[10] Országh, J., Water autarky - Sustainable water management for the world. www.eautarcie.org/en/

[11] Zseni, A., Waste or value? Human excreta as an important factor of the sustainable water management and agriculture (in Hungarian). Debreceni Müszaki Közlemények, 2014(2), pp. 75-84, 2014.

[12] Zseni, A., Human excreta management: human excreta as an important base of sustainable agriculture. Proc. of the 4th Multidisciplinary Academic Conference, Prague, pp. 1-8, 2015.

[13] Zseni, A., Human Excreta as an Important Factor of Sustainable Water Management and Agriculture. International Proceedings of Chemical, Biological and Environmental Engineering, 82, pp. 113-117, 2015.

[14] Zseni, A. \& Nagy, J., The role of human excreta in the future of agriculture (in Hungarian). Proc. of LVII. Georgikon Napok Konferencia. ed. Nagy, Z. B., Pannon Egyetem Georgikon Mezőgazdaságtudományi Kar: Keszthely, pp. 494-504, 2015.

[15] Data of population, data of environment. Hungarian Central Statistical Office, Budapest www.ksh.hu

[16] Christ, O. \& Mistsdoerffer, R., Regenerative Energie nutzen - Warmequelle Abal. wasser, WWT-Wasserwirschaft-Wassertechnik, 5, pp. 8-12, 2008.

[17] Domokos, E., A szennyvízkezelés fejlesztésének lehetőségei a magyar gazdaságban, manuscript. Proc. of Egyetemek, Föiskolák Környezetvédelmi Oktatóinak VII. Országos Tanácskozása, TIT: Kecskemét, 2015.

[18] Toilettes du Monde, Guide toilettes seches. Assaimissement Ecologique et solidarite: Nyons, p. 81, 2009. 
[19] Hungarian Central Statistical Office, Környezeti helyzetkép 2013. KSH: Budapest, pp. 17-24, 53-54, 2014.

[20] Stratégia 2014 Konzorcium, Szennyvíziszap kezelési és hasznositási stratégia 2014-2023, Országos Vízügyi Főigazgatóság: Budapest, pp. 7-8, 2014.

[21] Tanguay, F.: Petit manuel d'auto-construction. Mortagne: Quebec, pp. 1272, 1990.

[22] Feachem, R.G., Bradley, D.J., Garelick, H. \& Mara, D.D.: Sanitation and Disease. Health aspects of excreta and wastewater management. World Bank studies in water supply and sanitation. John Wiley and Sons: New York, pp. 4-5, 1983.

[23] Gao, X. Zh., Shen, T., Zheng, Y., Sun, X., Huang, S., Ren, Q., Zhang, X., Tian, Y., \& Luan, G., Practical manure handbook. (In Chinese). Chinese Agricultural Publishing House: Beijing, China, 2002. In: WHO, Guidelines for the safe use of wastewater, excreta and greywater. Volume 4. Excreta and greywater use in agriculture, pp. 9-10, 2006.

[24] Pieper, W., Das Scheiss-Buch - Entstehung, Nutzung, Entsorgung menschlicher Fäkalien. Der Grüne Zweig 123, Werner Pieper and Grüne Kraft: Germany, 1987. In: Jönsson, H., Stintzing, R., Vinnerås, B. \& Salomon, E., Guidelines on use of urine and faeces in crop production. Report 2004-2, Ecosanres, Stockholm Environment Institute: Stockholm, Sweden, p. 7, 2004.

[25] Schouw, N.L., Danteravanich, S., Mosbaek, H. \& Tjell, J.C., Composition of human excreta - a case study from Southern Thailand. Science of the Total Environment Journal, 286(1-3), pp. 155-166, 2002.

[26] Jönsson, H., Baky, A., Jeppson, U., Hellström, D. \& Kärrman, E., Composition of urine, faeces, greywater and biowaste for utilization in the URWARE model. Urban Water Report of the MISTRA Programme, Report 2005:6, Chalmers University of Technology: Gothenburg, Sweden, pp. 10 $21,2005$.

[27] Vinnerås, B., Palmquist, H., Balmér, P., Weglin, J., Jensen, A., Andersson, Å., \& Jönsson, H., The characteristics of household wastewater and biodegradable waste - a proposal for new Swedish norms. Urban Water Journal 3(1), pp. 3-11, 2006.

[28] Jönsson, H., Vinnerås, B., Höglund C., \& Stenström, T.A., Source separation of urine. Wasser und Boden, 51(11), pp. 21-25, 1999.

[29] Várallyai, Gy., Csathó, P. \& Németh, T., Az agrártermelés környezetvédelmi vonatkozásai Magyarországon, In: eds. Kovács, G., \& Csathó P., A magyar mezögazdaság elemforgalma 1901-2003 között. Agronómiai és környezetvédelmi tanulságok. MTA-TAKI: Budapest, pp. 155-188, 2005.

[30] Hungarian Central Statistical Office, Indicators for sustainable development for Hungary 2014. KSH: Budapest, pp. 42-43, 2015. 